\title{
Love and Belonging Needs in John Green's The Fault in Our Stars
}

\author{
Alvin Dwi Permana, Mamik Tri Wedawati ${ }^{2}$, and Muhammad Dhika Arif Rizqan ${ }^{3}$
}

\author{
${ }^{1}$ Universitas Negeri Surabaya \\ Surabaya, Indonesia \\ alvinpermana@mhs.unesa.ac.id \\ ${ }^{2}$ Universitas Negeri Surabaya \\ Surabaya, Indonesia \\ mamikwedawati@unesa.ac.id \\ ${ }^{3}$ UIN Sunan Ampel Surabaya \\ Surabaya, Indonesia \\ muh.dhika.arif.rizqan.m.pd@dlb.uinsby.ac.id
}

\begin{abstract}
The anxiety of being treated differently unlike others is one of the myriad uncomfortable feelings which may be understood by cancer sufferer. The present study aimed to expose the needs of two cancer sufferers who loved each other. They are the main characters of the Fault in Our Stars namely Hazel and Augustus. Therefore, the researchers addressed two questions: How are the love and belonging needs of Hazel and Augustus portrayed in John Green's The Fault in Our Stars? And what are the impacts of fulfilling love and belonging needs toward Hazel and Augustus as it is portrayed in John Green's novel The Fault in Our Stars? This study applied a qualitative approach namely content analysis. The data were analyzed and interpreted by using the hierarchy of needs which focused on love and belonging needs. The result exposed that Hazel and Augustus yearn for fulfilling their love and belonging needs instead of the other needs such as physiology, safety, self-esteem, and self-actualization. It affected significantly to their life which changed them to be more optimistic.
\end{abstract}

Index Terms - hierarchy of need, love need, belonging need.

\section{INTRODUCTION}

Human is a constructively social creature and it situates relation among others as a need. Social needs are fundamental elementary needs of human beings besides physical needs. Social needs can be articulated in the needs for social, belonging, love, and also affection (Maslow, 2008). In this term, the feeling of being belonged by someone else seems to be important to have by an individual. Without this need, someone can face existential anxiety. It is the anxiety of being alone and empty because nobody cares. The one will face the feeling of emptiness. This is what commonly happens to people with disabilities. They feel different and it makes them feel alone. They need the feeling of being belonged and loved. This is what people with disabilities or anyone with cancer feel as it is portrayed in John Green's The Fault in our Stars.
The novel narrated the story of Hazel Grace Lancaster; a 16-year-old girl with thyroid cancer which affects the work of her lungs. Her mother forced her to join a cancer patient support or sharing group. In that group, Hazel met a 17year-old boy, namely Augustus Waters. $\mathrm{He}$ got osteosarcoma that made him lose one of his legs. Augustus joined the group because he wanted to support his friend, Isaac who got eye cancer.

Hazel, Augustus, and Isaac were treated differently. They were viewed as similar to disabled people. It made them confronted by the psychological anxiety of being different. Being different may affect the emotional condition of the sufferer. Therefore, it can be assumed that the problem of the disabled or cancer people is the need for belonging and it is love need, as it is represented in Green's The Fault in Our Stars,

In the theory of needs, Maslow (2008) divided five kinds of needs. Those were physiology, safety, society (love and belonging), self-esteem, and self-actualization. Those five needs were arranged in a hierarchal structure 
which was known as the hierarchy of needs. Maslow saw that the needs of an individual represent human existence. It can be also seen as the root of motivation. The greater someone needs something, so the greater he or she wants to achieve a higher level of needs because it turns out to be motivation (William, 1974). In this hierarchy, the lowest need is a physiological need and the highest is a physiological need. To Maslow, all needs enable humans to get satisfied.

In detail, each need in this hierarchy can be described as follows. First, the physiological need is the most basic of all needs because the human body needs supplies such as food, sex, and oxygen (Cofer \& Appley, 1964; Reeve, 2014). Second, the safety need is the feeling of security. To obtain this feeling, someone can impose on the law the order, and the structure as the form of safety needs (Feist \& Feist, 2012). Third, the love and belonging need are what humans want about friendship, family bonds, or neighborhood (Feist \& Feist, 2012). Fourth, self-esteem need refers to the insight, perception, or prestige of one who achieves something in the eyes of others (Feist \& Feist, 2012). Fifth, the last, self-actualization refers to someone's need to become what he or she wants to be (Maslow, 2008). In general, the efforts to fulfill the needs are started from the physiological to the self-actualization need.

The hierarchy of needs was still popular to be used in the literature field until this decade. Here, the researchers presented five relevant studies. First, Mawaddah (2010) conducted a study to describe how does Santiago, the main character of The Alchemist, fulfills his needs. The finding revealed that Santiago was able to fulfill his physiological need easily but he was struggling to fulfill safety, love and belonging, and self-esteem needs. Second, Fiedhawatie (2013) analyzed the hierarchy of needs which is manifested by the main character in Forrest Gump the movie. It was found that the main character, Forrest Gump, has physiological, safety, love and belonging, self-esteem, and self-actualization. Although he could not walk properly at first, he succeeds to walk and even run after he was able to overcome his needs. Third, Maria (2014) tried to reveal what kind of problems appear from the unfulfilled love need in the main character of Anton Chekov's Misery. The result showed that the unfulfillment of the basic needs caused complex problems. It was caused by the balance between his need and desire. Fourth, Junaidi (2014) conducted a study to analyzed Gatsby's physiological problems and his solutions to overcome the problems. One of the results showed that Gatsby could not fulfill his love and belonging need in the end. However, Gatsby did some efforts to fulfill these needs such as living near the woman he loves. Fifth, Setiawan (2018) aimed to inquire about the level of life needs which are wanted to be quickly achieved as the key success in T. B. Silalahi's novel Toba Dreams. The findings indicated that all antagonists' life needs could be achieved by hook or by crook.

Although all previous studies used the hierarchy of needs, they did not explore the characters' motivation to keep alive which is sourced in the fulfillment of the needs. Therefore, in this study, the researchers aimed to expose the fulfillment of (love and belonging) needs in The Fault in Our Stars where the characters were suffering because of their cancer as one of the near-death experiences. The feeling of anxiety of being different, not being treated like others who did not have cancer, becomes the crucial part to relate with the need they want. Thus, two questions were addressed: How are the love and belonging need of Hazel and Augustus portrayed in The Fault in Our Stars? and how are the impacts of fulfilling love and belonging need towards Hazel and Augustus as it is portrayed in The Fault in Our Stars?.

\section{METHOD}

This study was categorized into a content analysis study. It is one type of qualitative research that focuses on scrutinizing and interpreting documents or any other records (Ary, Jacobs, Sorensen, \& Razavieh, 2010). The source of the data was John Green's sixth novel entitled The Fault in Our Stars. It was firstly published in January 2012 by Dutton Books. The novel consists of 313 pages.

Here, the content analysis study involved four steps in collecting and analyzing the data. First, the researchers read the novel repetitively and interpretatively. It was conducted to understand and perceive the novel comprehensively. Second, marking all dialogs and paragraphs which were possibly related to Maslow's (2008) love and belonging need. As a result, the data were in the form of quotations. Third, these data were classified according to the research questions. Fourth, interpreting the data under the social constructivism paradigm because this paradigm was relevant to the objective of this study which aimed to rely as much as possible on the characters' views of the situation (Creswell, 2007).

\section{RESULT AND DISCUSSION}

\section{A. The Portrayed of Love and Belonging Need in Green's The Fault in Our Stars}

Love and belonging are related to social needs. It means that Hazel and Augustus lived as a social beings and they need to be cared for and treated as normal people. Of course, some cases explain their need to be loved and belonged by someone else, especially to someone they love; Hazel to Augustus and Augustus to Hazel. Hazel and Augustus shared one similarity, cancer. Cancer made them depressed

\section{Hazel's Love and Belonging Need}

Before it went further, it was important to know the background of Hazel. Hazel Grace Lancaster is a sixteenyear-old girl who has cancer. She is the only child of Mr. and Mrs. Lancaster. She is Augustus Waters' girlfriend. Hazel is portrayed to have already started to get a college education. She has Stage IV Thyroid cancer in her lungs. However, with great struggle, she tries to live with an experimental drug (Phalanxifor). 
In the first part of the novel, Hazel's mother knew that Hazel is miserable. She sent Hazel to a hare group each Wednesday. It was held in a church crypt. The group namely The Literal Heart of Jesus is led by Patrick. In that group, Hazel met Augustus. Augustus is the first person who said that Hazel is beautiful. Augustus explained that he enjoyed staring at beautiful people. During the days in the support group, Hazel and Augustus were getting closer. They also made friends with Isaac and Monica. By the time, Isaac and Monica also were getting closer. Augustus knew and told to Hazel that they have promised to always be together and always love each other.

From those expositions of Hazel's background, it was known that Hazel has a dangerous illness that may cause death for her. In this situation and condition, of course, Hazel is depressed. Before she met Augustus and joined the support group, she just laid in bed because of her thyroid cancer.

Late in the winter of my seventeenth year, my mother decided I was depressed, presumably because I rarely left the house, spent quite a lot of time in bed, read the same book over and over, ate infrequently, and devoted quite a bit of my abundant free time to thinking about death. (Green, 2012, p. 3)

From the quotation, it implied that there were some kinds of anxiety because of cancer. Her mother thought that Hazel is depressed. Her mother saw that Hazel had never socialized and it indicated that Hazel needed social relations. The quotation mentioned important points, especially about the portrayal of what Hazel needed. If Hazel had never gone out of her room because of her cancer, it meant that the cancer is the source of the social problem of Hazel. If it was so, it meant that what Hazel needed is social needs (i.e. love and belonging).

The value of the love and belonging need is very crucial or important. Looking back at Hazel's condition, she has a really serious disease, thyroid cancer. This cancer is growing from the flesh of the thyroid gland. It is a disease in that cells grows unusually. In this sense, it is important to know that there are four main kinds of cancers: papillary thyroid, follicular thyroid, medullary thyroid, and anaplastic thyroid. Diagnosis is usually operated from the ultrasound. Treatment options can be surgery and radiation therapy such as thyroid hormone, chemotherapy, watchful waiting, targeted therapy, and radioactive iodine (Carling \& Udelsman, 2014). Watchful waiting with doses of experimental drugs was what Hazel did to struggle against her cancer.

Cancer became the main reason to imply what Hazel needed. She needed love and belonging. It was reflected in how she did not want to get out of her room. Her mother understood what Hazel needs, so she asked Hazel to join a group, and she met Augustus.

Furthermore, Hazel is very sympathetic and unselfish. She is also known for a good way of thinking. He likes thinking about the universe. Meeting with Augustus also made Hazel constantly read a book like what Augustus likes. Augustus offered her to read a novel, An Imperial Affliction, written by Peter Van Houten. It was a series novel and the ending was still unknown. Because she was very obsessed with the novel, she wished that before she dies, she wanted to know the end of the novel. Of course, Augustus tried to make it true.

What Augustus did and the presence of Augustus in Hazel's life was actually what Hazel needed. Augustus seemed to be the one she needed. Augustus brought love and always makes Hazel felt she belongs to him. It was important to shaping the power Hazel to keep alive. Of course, Augustus loves Hazel. This love happened because they shared a similar condition. Hazel is a marginalized girl. With cancer, she might have thought and felt that no boy can love her. This unconsciousness led Hazel to love Augustus, especially knowing Augustus always supports her in everything. It was not just love in the direct expression. It was more about how Augustus directed Hazel to enjoy life even if cancer haunted her. Therefore, Augustus offered a discussion of hobbies and something like that as Hazel's need for love and belonging.

"Why are you looking at me like that?"

Augustus half-smiled. "Because you're beautiful. I enjoy looking at beautiful people, and I decided a while ago not to deny myself the simpler pleasures of existence." A brief awkward silence ensued. Augustus plowed through: "I mean, particularly given that, as you so deliciously pointed out, all of this will end in oblivion and everything."

I kind of scoffed or sighed or exhaled in a way that was vaguely coughy and then said, "I'm not beau-"

"You're like a millennial Natalie Portman. Like V for Vendetta Natalie Portman" (Green, 2012, p. 18).

From the quotation, Augustus said something to Hazel that Hazel is beautiful. For a girl with a pipe in her nose and cancer that could threaten her, this compliment, praise, or admiring comment is something special. She felt that no boy can love her but Augustus saw her as a beautiful girl. For sure, it was what Hazel needed, love. She just wanted to be loved. She felt alone with cancer; therefore she never got out of her room. Knowing Augustus compared her to Natalie Portman made Hazel seemed to realize that she belongs to Augustus. Augustus is her need.

Natalie Portman is known as an American film actress, director, producer, and writer. She has received various awards such as an Academy Award and two Golden Globe Awards (Dickerson, 2002). Of course, being compared to a famous actress became a point to explain that Augustus was the reason why she wants to struggle against cancer she has. Augustus is the manifestation of love and belonging needs that she needs.

The way Augustus treated her results in the same way. Hazel also felt the same. She started to feel that Augustus is the love need for her. However, she felt a little bit nervous to express back her feeling. Then, it was known that she needed a moment to tell him about her feeling for Augustus. 
"I couldn't stop thinking about the little moment when I'd tensed up as he touched me. The gentle familiarity felt wrong, somehow. I thought maybe it was how orchestrated the whole thing had been: Augustus was amazing, but he'd overdone everything at the picnic, right down to the sandwiches that were metaphorically resonant but tasted terrible and the memorized soliloquy that prevented conversation. It all felt Romantic, but not romantic"(Green, 2012, p. 21).

From the quotation, it showed that she was a little bit chaotic about her feeling for August. However, August always gets her to feel relaxed with him. When someone's treatment turns to be a need for someone else, then its presence cannot be denied. Hazel could not understand what she felt because before, she did not have the love and belonging needed. She has parents and she is the only child in her family, but she did not meet someone who treated her love and belonging liked Augustus was doing.

\begin{abstract}
"We crawled into the bed, my freedom circumscribed some by the oxygen, but even so I could get on top of him and take his shirt off and taste the sweat on the skin below his collarbone as I whispered into his skin, "I love you, Augustus Waters," his body relaxing beneath mine as he heard me say it. He reached down and tried to pull my shirt off, but it got tangled in the tube. I laughed"'(Green, 2012, p. 17).
\end{abstract}

The quotation explained an important moment when Hazel and Augustus shared a bed to make love. Making love could be a kind of symbol that Augustus had become Hazel needed. She wanted to be loved. Augustus could deliver it and this is why Hazel opened her mind to make love to Augustus because she felt that Augustus was the only one she could love. This moment also showed that Hazel also fell in love with Augustus. There was a sentence of "I love you, Augustus Waters" that explained all feelings of Hazel. This feeling represented the need for love and belonging for Hazel Grace. At this moment, also, it explained that Hazel needed of love and belonging from Augustus made her forgot about her cancer. When someone's need is fulfilled, then the other problem can be covered for a moment and it is crucial to motivate someone against something that stopped him or her from hoping and struggling.

In the crucial moment, when Hazel was feeling so ill, Augustus also became the one Hazel wanted to be with,

"Mom and Dad left us alone, which felt awkward. I worked hard to meet his eyes, even though they were the kind of pretty that's hard to look at" (Green, 2012, p. 110).

It explained clearly that Augustus' love was what Hazel needed. Of course, her parents were important too, but the point was, as a cancer sufferer, Hazel needed care, love, and belonging.

Just before the Miracle, when I was in the ICU and it looked like I was going to die and Mom was telling me it was okay to let go, and I was trying to let go but my lungs kept searching for air, Mom sobbed something into Dad's chest that I wish I hadn't heard, and that I hope she never finds out that I did hear. She said, -I won't be a mom anymore. It gutted me pretty badly (Green, 2012, pp. 116-117)

As it was exposed before, there was a moment when Hazel's cancer caused her was dying. Her parents just stared at Hazel with torment, pain, and suffer. They became a pair of the witness for her daughter was dying, but Hazel wanted Augustus because she felt that Augustus could feel what she felt. The way Hazel's parents, especially her mother, starred and cried for Hazel could release Hazel's burden that her mother gave her love and belonging need.

"But she kept asking as if there were something she
could do until finally I just kind of crawled across the
couch into her lap and my dad came over and held my
legs tight and I wrapped my arms around my mom's
middle and they held on to me for hours while the tide
rolled in" (Green, 2012, p. 266).

The quotation was her mother's dialog with Hazel. It implied that her mother always gives love to Hazel. Hazel must have felt it and it was what Hazel needed. Her mother always asks Hazel what she has to do to lessen her pain, but Hazel kept silent. Her mother kept asking what she is supposed to do, and then Hazel hugged her mother. Her mother's care revealed love and belonging. Hazel felt that her mother loved her. She also felt that her mother wanted her. It was important for Hazel because it explained that her mother felt that Hazel was important for her.

\section{Augustus's Love and Belonging Need}

Augustus Waters is a boy and he is the best friend of Isaac. He falls in love with Hazel Grace's and with her, he struggled against cancer he has, osteosarcoma. Augustus is portrayed as a tall, handsome, clever, blue-eyed, and mahogany-haired boy. With those portrayals, he seems to be a perfect boy. However, he is a one-footed boy with cancer in his body. This flaw is permanent and it fears him up. He scares of forgetfulness. He wanted to make a kind of legacy in the world due to his diagnosis of cancer.

Augustus met Isaac before the share group. He joined the support group just because he wanted to support Isaac. Isaac is afraid of undergoing surgery, so Augustus supported him by joining the group where Isaac joined it too. Augustus often gave up on his cancer, but he always covers it because he wants to look strong. Hazel herself portrayed Augustus as well built-seeing boy because he likes playing basketball with a robotic-assisted foot. His 
right leg is replaced with a prosthetic due to his osteosarcoma.

Osteosarcoma (OS) is a kind of tumorous in a bone. In detail, it is an aggressive dangerous neoplasm which is from primitive malformed cells of mesenchymal source and it shows the osteoblastic difference and produces dangerous osteoid (Luetke, Meyers, Lewis, \& Juergens, 2014). Osteosarcoma has been the most usual histological shape of bone cancer. It is most dominant in young adults (Ottaviani \& Jaffe, 2009). This disease is what makes Augustus lost his leg.

As it was told before, Hazel is Augustus's girlfriend. Augustus firstly met Hazel in the support group. Augustus and Hazel began as a friend, after watching movies together, playing video games, and talking about Hazel's favorite book, An Imperial Affliction, they became love partner. Their love led them to Amsterdam in the hunt for the ending of the novel. Regrettably, they did not find out what they looked for.

If it had to see clearly, Augustus is so kind and nice to Hazel. What Augustus did to Hazel showed that Augustus needed love and belonging. It is not about what someone receives, but it is also about what someone does to others because when people do something to the other, they receive some kind of feeling of being accepted. This kind of feeling referred to love and belonging need as it was perceived by Augustus. He is always kind to Hazel and Hazel loves that. The way Hazel loved him was an example of how Augustus needed love and belonging. One of the important moments was when Augustus supported Hazel to meet the author of her favorite novel in Amsterdam. However, there was a problem for Hazel to go there.

I can't go to Amsterdam. One of my doctors thinks it's a bad idea.

(Green, 2012, p. 118)

Hazel told Augustus that she could not go to Amsterdam because her doctor who handles her cancer said that it might cause a serious problem in her condition. Thus, Hazel canceled her wish to go to Amsterdam. She wanted to go to Amsterdam to see the author of her favorite novel, Peter Van Houten. She just wanted to ask about the ending of the novel. That proved that Augustus loves Hazel and Hazel loves Augustus. It was what Augustus needed, love and belonging need.

There was a moment when things seemed to come to an end. Augustus, as a cancer sufferer, would also confront the dying moment. Hazel was so scared. She did not want to lose Augustus as Augustus did not want to lose Hazel. In the beginning, it was told that Augustus was often depressed because his cancer almost made his life oblivion and took his left leg.

I fear oblivion," he said without a moment's pause. "I fear it like the proverbial blind man who's afraid of the dark. (Green, 2012, p. 14)
Augustus was scared of oblivion. Oblivion is a kind of feeling of destruction or extinction (Prewitt, 1993). Behind his strong feeling and good spirit, Augustus was devastated by his condition like a cancer sufferer. The illness was the factor he needed a relationship with. Both Hazel and Augustus have the same condition and it influenced their relationship.

In this novel, Hazel and August love each other. August loves Hazel no matter what she is. The positive qualities of Augustus are literate, warm, cheerful, positive thinking, and good. He could take Hazel to another place outside her house, he could make Hazel keep chasing her dream, and looking at Hazel's smile is the most important thing for him. Hazel's happiness is what he needs.

\section{B. The Impact of Fulfilling Love and Belonging Need in Green's The Fault in Our Stars}

The essence of love and belonging need is relationship or interaction. Two or more individuals can be said to have shaped a relationship when they are on occasions to meet, interact, and share with others. By this kind of interaction, they produce behavior to be social to each other.

Hazel and Augustus are partners in a love relationship. Their relationship has something unique because the two have cancer and they fill the lack in their feeling for each other. Their illness made them responsible for each other. From this condition, they needed each other and their needs are love and belonging. Of course, some impacts could be exposed to fulfilling this need such as appreciated feeling, high-valued feeling, and loved the feeling.

The appreciated feeling can be related to rewards. Rewards can give a feeling of relief, pleasure, and satisfaction that makes someone enjoy a relationship. Of course, it is a kind of positive element to raise good results in the relationship.

\section{"Why are you looking at me like that?" Augustus half-smiled. "Because you're beautiful. I enjoy looking at beautiful people, and I decided a while ago not to deny myself the simpler pleasures of existence." \\ His every syllable flirted. Honestly, he kind of turned me on. I didn't even know that guys could turn me on-not, like, in real life" (Green, 2012, p. 22).}

The quotation simply exposed a simple conversation of how Augustus gave relief to Hazel from his words and Hazel was flattered. It was a kind of appreciation that is sourced from being loved and belonged. Hazel was pleased but a little bit nervous because it was the first time someone else called her beautiful. Being loved and being belonged was the need for Hazel because she felt special (as a cancer sufferer). Hazel's happiness was the consequence of Augustus' appreciation and August's appreciation was the impact of his need to love and be loved by someone else.

In the relationship between Hazel and Augustus, they spent time, energy, and hope together. It bound them in a 
tight connection. When someone is tied up in a tight connection, they need each other. When they need each other, there is a kind of possessive drive that controls their relation, for example, Hazel is used to feeling distaste for Augustus's attitude when he smoked. Even if Augustus explained that it was only a metaphor, but Hazel still disliked it.

\begin{abstract}
"Are you serious?" I asked. "You think that's cool? Oh, my God, you just ruined the whole thing."

"Which whole thing?" he asked, turning to me. The cigarette dangled unlit from the unsmiling corner of his mouth.

...

I felt this weird mix of disappointment and anger welling up inside of me. I don't even know what the feeling was just that there was a lot of it, and I wanted to smack Augustus Waters and also replace my lungs with lungs that didn't suck at being lungs (Green, 2012, p. 30).
\end{abstract}

When Hazel knew that it was only a metaphor, Hazel could accept it. It showed that at the first moment Hazel was disappointed in Augustus, she was already in feeling with Augustus. It is very simple to understand, just like a moment when people are angry with their friend, we always think of him her. People think of him or her because there is something that cannot be thrown away. It is friendship. It means that love and belonging need makes us get bound and tied up with someone else. It was what happened to Hazel and Augustus. The way Hazel was angry with August because Augustus was what she needed to love and belong. Augustus should keep alive. Therefore, the cost must be paid with the consequence such as disappointment, anger, and so on. Hazel never felt bad when she must pay it up just because she wanted to maintain her relationship.

From that perspective, it could be known that Hazel and Augustus have good a relationship. They combined a set of cancer and love to be goodness called to love and belonging need. Beyond those things, the greatest impact of their love and belonging need was how they struggled and motivated themselves to keep living as well. Culture (or environment, including friends) also influenced one's behavior (Guimón, 2004). It gave an impact on one's motivation in life. Therefore, one shows motivation and motivation is a reflection of one's needs. Desire, love, or anything that pushes can be also seen as a need that activates behavior to aim for a purpose in life (Schacter, Gilbert, Wegner, \& Hood, 2011). The needs of one are also seen as the main source of motivation. It makes an individual do something.

Augustus loves Hazel. The love he got from Hazel seems to be greater than the love he got from his family. It affected his motivation to do something beyond his power. He always spends his time with Hazel and even, tried to contact the author Hazel wanted to meet up with. He did everything just for Hazel because Hazel gave what he needed, love and belonging.
Now, I'm not going to give you my wish or anything. But I also have an interest in meeting Peter Van Houten, and it wouldn't make sense to meet him without the girl who introduced me to his book ... So I talked to the Genies, and they are in total agreement. They said Amsterdam is lovely at the beginning of May. They proposed leaving May third and returning May seventh ... Sure I do," he said. "I found my wish. (Green, 2012, pp. 89-90)

What Augustus wants was just to make Hazel happy. It gave more relief than thousands of loves he got from his family. Augustus wanted to share affection with Hazel because it was the impact of the love and belonging, he gets from Hazel. That was the point of Augustus. In this sense, love and belonging need make someone gets motivated as the impact of its fulfillment.

\section{CONCLUSION}

All in all, it was found that Hazel's love and belonging need were portrayed in some cases. It was not only about their love story but also how psychologically Hazel felt enthusiastic in her life after met Augustus. It indicated that love and belonging need was the thing that Hazel needed instead of something else. Support becomes the most critical thing because it makes the sufferers feel that they are important. In this case, Hazel felt alive and even she and Augustus chased their hope to meet her favorite novel author in Amsterdam which was too risky because she might pass it out.

Hazel and Augustus fulfilled their needs of love and belonging were about how love and belonging need changed their life. Hazel who is a pessimistic girl becomes very enthusiastic. She can feel the love from someone who truly loves her as she is. Augustus who is an optimistic boy becomes more enthusiastic because there is always someone who loves him even if on his last day or his funeral not submit a reworked version of a paper you have submitted or published elsewhere. Do not publish "preliminary" data or results. The submitting author is responsible for obtaining the agreement of all coauthors and any consent required from sponsors before submitting a paper. IRSC UNUD JOURNALS strongly discourages courtesy authorship. The authors should cite relevant prior work.

\section{REFERENCES}

[1]Ary, D., Jacobs, L. C., Sorensen, C. K., \& Razavieh, A. (2010). Introduction to Research in Education (Vol. 8). Belmont: Wadsworth Cengage Learning.

[2]Carling, T., \& Udelsman, R. (2014). Thyroid cancer. Annual review of medicine, 65, 125-137.

[3]Cofer, C. N., \& Appley, M. H. (1964). Motivation: Theory and research.

[4]Creswell, J. W. (2007). Qualitative Inquiry \& Research Design: Choosing Among Five Approach (Second ed.). Thousand Oaks: Sage Publications. 
[5]Dickerson, J. L. (2002). Natalie Portman: Queen of Hearts: ECW Press.

[6]Feist, J., \& Feist, G. (2012). Theories of Personality. Boston: McGraw Hill.

[7]Fiedhawatie, S. D. (2013). Maslow's Hierarchy of Needs Manifested by the Main Character in the Forrest Gump The Movie. Bachelor Thesis, Universitas Brawijaya, Malang.

[8]Green, J. (2012). The Fault in Our Stars. New York: Dutton Books.

[9]Guimón, J. (2004). Relational mental health: Beyond evidence-based interventions: Springer Science \& Business Media.

[10] Junaidi, A. N. (2014). Psychological Analysis of Jay Gatsby's Life in Francis Scott Fitzgerald's "The Great Gatsby" (Viewed from Abraham Maslow Hierarchy of Needs Theory). Bachelor Thesis, Universitas Negeri Maulana Malik Ibrahim, Malang.

[11] Luetke, A., Meyers, P. A., Lewis, I., \& Juergens, H. (2014). Osteosarcoma treatment-where do we stand? A state of the art review. Cancer treatment reviews, 40(4), 523-532.

[12] Maria, G. I. (2014). The Unfulfilled Love Need in the Main Character of Anton Chekov's Misery. Bachelor Thesis, Universitas Brawiyaya, Malang.

[13] Maslow, A. (2008). Motivation and Personality. New York: Herper.

[14] Mawaddah, S. (2010). A Main Character Analysis of The Alchemist by Paulo Coelho Using Hierarchy of Human Needs of Abraham H. Moslow's Theory. Bachelor Thesis, Universitas Islam Syarif Hidayatullah, Jakarta.

[15] Ottaviani, G., \& Jaffe, N. (2009). The epidemiology of osteosarcoma Pediatric and adolescent osteosarcoma (pp. 3-13): Springer.

[16] Prewitt, J. (1993). Facing Oblivion. The Southern Review, 29(3), 481.

[17] Reeve, J. (2014). Understanding motivation and emotion: John Wiley \& Sons.

[18] Schacter, D., Gilbert, D., Wegner, D., \& Hood, B. M. (2011). Psychology: European Edition: Macmillan International Higher Education.

[19] Setiawan, A. (2018). Needs Hierarchy in T. B. Silalahi's Novel Toba Dreams. Paper presented at The 1st Annual International Conference on Language and Literature (AICLL).

[20] William, B. A. (1974). Theories of Personality. New York: MacMillan. 